\section{AORTIC BIOPROSTHESIS- AVOID OBSTRUCTIVE \\ PROPERTIES DUE TO \\ THROMBOSIS AS ALTERED \\ DURABILITY DUE TO \\ STRUCTURAL VALVE \\ DETERIORATION}

\section{To the Editor:}

The brief communication entitled "Early stenosis of Medtronic Mosaic porcine valves in the aortic position" by Lawton and colleagues ${ }^{1}$ was published in the June issue of the Journal. The authors reported 4 cases of early altered durability of the aortic Medtronic Mosaic porcine bioprosthesis causing stenosis of undetermined cause after university site and manufacturer pathological evaluations.

At the time the article was in press, we were visiting the California facility of Medtronic, Inc, examining the prosthesis explants from the 6 longitudinal study centers in preparation for the meeting of the Society of Heart Valve Disease. We had the opportunity to view photographs of the valves (2 presented in color reproduction in the article) and to review the pathological reports. The reports documented pannus overgrowth of up to $3 \mathrm{~mm}$ from the margins of the prosthesis sewing cuff onto the leaflets of all 4 valves. Two of the valves had evidence of coagulated blood partially in the outflow of the cusps, whereas the other 2 had extensive host thrombotic material filling the outflow of all cusps.

\footnotetext{
The Editor welcomes submissions for possible publication in the Letters to the Editor section that consist of commentary on an article published in the Journal or other relevant issues. Authors should: • Include no more than 500 words of text, three authors, and five references. • Type with double-spacing. • See http://jics.ctsnetjournals.org/misc/ifora.shtml for detailed submission instructions. - Submit the letter electronically via jtcvs.editorialmanager.com. Letters commenting on an article published in the JTCVS will be considered if they are received within 6 weeks of the time the article was published. Authors of the article being commented on will be given an opportunity of offer a timely response ( 2 weeks) to the letter. Authors of letters will be notified that the letter has been received. Unpublished letters cannot be returned.
}

The authors reported these findings in 4 of 106 patients with the Mosaic prosthesis. The study cohort of 106 aortic patients was accrued between August 17, 2001, and December 5, 2005. We noted from Table 1 of the communication that patient $\mathrm{D}$ had an implant date in 2007. We further learned that only 2 of the 4 valves discussed in the communication were implanted in the reporting center, only one with complete thrombosis of the prosthesis, thus resulting in a ratio of 1 of 106 patients.

The radiographs were reported as part of the pathological reports, showing no mineralization of valve tissue in 3 and remnants of mineralization of host tissue on the sewing ring of the other prosthesis.

The magnitude of prosthesis thrombosis has been previously reported by us. In 2004, Fradet and associates, ${ }^{2}$ reporting on the 1029 patients in the 6-center longitudinal study, identified 3 cases of aortic prosthesis thrombosis and no cases of structural valve deterioration.

In 2005, Jamieson and coworkers, ${ }^{3}$ reporting on 657 patients from the University of British Columbia, confirmed 3 cases of thrombosis ( 2 aortic and 1 mitral) and 4 cases of structural valve deterioration (3 with tears and mild/moderate calcification and 1 with severe calcification accompanying renal failure).

We agree with the authors that causative factors of thrombosis have not been determined, except that Riess and associates ${ }^{4}$ have reported abnormal coagulation profile.

The "Guidelines for reporting mortality and morbidity after cardiac valve interventions" ${ }^{, 5}$ clarifies structural valve deterioration (referring to altered durability), thrombosis, and nonstructural dysfunction. Lawton and colleagues $^{1}$ are considering pannus (nonstructural dysfunction) and thrombosis as durability issues. In these elderly patients ( $>70$ years of age) there is no evidence of structural valve deterioration representing early altered du- rability. The thrombosis cause requires further investigation and coagulation evaluation on a case-by-case basis.

\section{W. R. Eric Jamieson, $M D$ \\ Guy J. Fradet, MD \\ Department of Surgery \\ University of British Columbia \\ Vancouver, British Columbia \\ Canada}

\section{References}

1. Lawton JS, Moazami N, Pasque MK, Moon MM, Damiano RJ Jr. Early stenosis of Medtronic Mosaic porcine valves in the aortic position. J Thorac Cardiovasc Surg. 2009;137:1556-7.

2. Fradet GJ, Bleese N, Busse E, Jamieson WRE, Raudkivi P, Goldstein J, et al. The Mosaic valve clinical performance at seven years: Results from a multicentre prospective clinical trial. J Heart Valve Dis. 2004;13:139-47.

3. Jamieson WRE, Fradet GJ, MacNab JS, Burr LH, Stanford EA, Janusz MT, et al. Medtronic Mosaic porcine bioprosthesis: investigational centre experience to six years. J Heart Valve Dis. 2005; 14:54-63.

4. Riess FC, Cramer E, Hansen L, Schiffelers S, Wahl $\mathrm{G}$, Wallrath J, et al. Clinical results of the Medtronic Mosaic valve in the aortic position. Eur J Cardiothorac Surg. In press.

5. Akins CW, Miller DC, Turina MI, Kouchoukos NT, Blackstone EH, Grunkemeier GL, et al. Guidelines for reporting mortality and morbidity after cardiac valve interventions. J Thorac Cardiovasc Surg. 2008;135:732-8.

doi:10.1016/j.jtcvs.2009.12.044

\section{INTERPRETING A 20-YEAR EXPERIENCE WITH THE BIOCOR PORCINE BIOPROSTHESIS}

\section{To the Editor:}

With greatest interest we read the recent article by Drs Mykén and BechHausen. ${ }^{1}$ The authors reported on a 20-year experience of 1712 patients with the Biocor porcine bioprosthesis. The study reported excellent long-term prosthetic valve durability in both the aortic and mitral positions over a 20 year period. Comparing the data with those for other types of bioprostheses, the Biocor devices were shown to rival the best valves around.

A few comments and a word of caution seem to be appropriate and of interest to the readership of the Journal to interpret these data. The authors correctly state that comparisons with 
other long-term studies are difficult because of differing baseline characteristics. ${ }^{1}$ Comparisons are subsequently provided and summarized in Table 5; however, considerations concerning some key patient cohort differences are lacking. ${ }^{2-4}$ These include the following.

First, the continuing patient enrollment during a 20-year period resulted in a limited mean follow-up time: $6.0 \pm 4.5$ years for aortic valve replacement (AVR) and $6.2 \pm 5.6$ years for mitral valve replacement. This strategy tends to underestimate events in comparison with similar studies with a much shorter enrollment period like the cited 20-year Edwards Clinical Communiqué, which had a mean follow-up time of $9.0 \pm 5.5$ years. $^{2}$

Second, the authors report the actuarial freedom from reoperation because of structural valve deterioration (SVD), which is inherently lower than the freedom from SVD. Therefore the direct comparison with the freedom from SVD as reported by several other studies tends to underestimate the number of events in the current study. 3,4

Third, the long inclusion period has resulted in an uneven age distribution over time. Given the mean age difference between the originally reported 10-year experience and the current 20-year report, patients in the AVR and mitral valve replacement cohorts, respectively, must on average have been about 7 and 5 years older during the second decade of the study than during the first decade. ${ }^{1,5}$ Therefore a high number of patients with a relatively short follow-up time might contribute to an underestimation of the incidence of SVD in the elderly groups. ${ }^{2}$

A further comment is directed at the intriguing incompleteness of Table $5 .{ }^{1}$ Age-stratified event rates for AVR from several studies are cited in the last column, headed by the Biocor's 20-year freedom from reoperation because of SVD being $92.1 \% \pm 3.9 \%$ in patients aged 65 years and older and
$44.5 \% \pm 9.2 \%$ in those younger than 65 years. However, for 2 studies these readily available data are provided as mean overall rates only., ${ }^{3,4}$ The excellence of these results in the elderly patient groups makes these data indispensable for the overall perspective. The $68 \% \pm 12 \%$ overall freedom from SVD in Aupart and colleagues' 18-year Perimount experience ${ }^{3}$ thus breaks down into $99 \% \pm 1 \%$ for patients aged greater than 70 years, $77 \%$ $\pm 12 \%$ for those aged 60 to 70 years, and $45 \% \pm 15 \%$ for those aged less than 60 years. In Yankah and associates' 17-year Mitroflow experience, ${ }^{4}$ the $67.0 \% \pm 4.9 \%$ freedom from SVD in similar age groups breaks down into $93.0 \% \pm 3.0 \%, 60.1 \% \pm 6.4 \%$, and $45.7 \% \pm 13.5 \%$, respectively.

We congratulate the authors with the realization of their study spanning so many years and hope to see further results and adequate comparisons in future publications.

\section{Willem J.L. Suyker, MD, PhD \\ Frans G. Leicher, MD \\ Department of Cardiothoracic \\ Surgery \\ Isala Clinics \\ Zwolle, The Netherlands}

\section{References}

1. Mykén PS, Bech-Hansen O. A 20-year experience of 1712 patients with the Biocor porcine bioprosthesis. J Thorac Cardiovasc Surg. 2009;137:76-81.

2. Clinical Communiqué: Carpentier-Edwards Perimount pericardial aortic bioprosthesis 20 year results. Irvine, Calif: Edwards Lifesciences; 2003. Available at: http://www.edwards.com/products/heartvalves/peri mountaorticcommuniquepdf.htm. Accessed April 6, 2009.

3. Aupart MR, Mirza A, Meurisse YA, Sirinelli AL, Neville PH, Marchand MA. Perimount pericardial bioprosthesis for aortic calcified stenosis: 18-year experience with 1,133 patients. J Heart Valve Dis. 2006;15:768-76.

4. Yankah CA, Schubel J, Buz S, Siniawski H, Hetzer R. Seventeen-year clinical results of 1,037 Mitroflow pericardial heart valve prostheses in the aortic position. J Heart Valve Dis. 2005;14:172-9.

5. Mykén PS, Caidahl K, Larsson S, Berggren HE. 10-year experience with the Biocor porcine bioprosthesis in the aortic position. J Heart Valve Dis. 1994; 3:648-56.

doi:10.1016/j.jtcvs.2009.04.070

\section{THE SECOND ASSISTANT IN CARDIAC SURGERY \\ To the Editor:}

I thank Dr Zamvar for his appreciative comments ${ }^{1}$ on my editorial entitled "The second assistant in cardiac surgery: the challenges and answers.", As Dr Zamvar rightly points out, the position of second assistant is to be seen as a great opportunity for surgical training and not a burden. As surgical trainees, we often have the mindset that surgical training is all about cutting and suturing, of doing rather than watching. The second assistant position in a way enforces a temporary pause in this "cutting and suturing" ritual, allowing the trainee to think and redefine his or her techniques. Indeed, it is very easy for the mind to drift, and the trainee has to make a conscious effort to stay focused. The ability to make sharp observations and stay focused for long durations is often not an innate skill and has to be developed over time. These mental faculties are as important as hand skills in the making of a good surgeon. The second assistant position offers a unique opportunity to develop these skills. I also agree with Dr Zamvar that the new laws enforcing limited hours of working on trainees ${ }^{3}$ will take away a great opportunity from the current generation of surgical trainees.

T. K. Susheel Kumar, MD Department of Cardiovascular Surgery

Children's National Medical Centre Washington, $D C$

\section{References}

1. Zamvar V. They also serve who only stand and wait. J Thorac Cardiovac Surg. 2010;139:798.

2. Kumar TK. The second assistant in cardiac surgery: the challenges and answers. $J$ Thorac Cardiovasc Surg. 2009; 137:1311-4.

3. Council of the European Union. The European working time directive. Council Directive. Brussels, Belgium: Council of the European Union; 1993. Publication no. 93/104/EC.1993.

doi:10.1016/j.jtcvs.2009.10.066 